\title{
Sports Medicine
}

\section{Variability in the study quality appraisals reported in systematic reviews on the acute:chronic workload ratio and injury risk \\ --Manuscript Draft--}

\begin{tabular}{|c|c|}
\hline Manuscript Number: & SPOA-D-20-00615 \\
\hline Full Title: & $\begin{array}{l}\text { Variability in the study quality appraisals reported in systematic reviews on the } \\
\text { acute:chronic workload ratio and injury risk }\end{array}$ \\
\hline Article Type: & Letter to the Editor \\
\hline \multicolumn{2}{|l|}{ Funding Information: } \\
\hline Corresponding Author: & $\begin{array}{l}\text { Greg Atkinson, PhD } \\
\text { Teesside University } \\
\text { Middlesbrough, North Yorkshire UNITED KINGDOM }\end{array}$ \\
\hline \multicolumn{2}{|l|}{$\begin{array}{l}\text { Corresponding Author Secondary } \\
\text { Information: }\end{array}$} \\
\hline Corresponding Author's Institution: & Teesside University \\
\hline \multicolumn{2}{|l|}{$\begin{array}{l}\text { Corresponding Author's Secondary } \\
\text { Institution: }\end{array}$} \\
\hline First Author: & Gregory MacMillan \\
\hline \multicolumn{2}{|l|}{ First Author Secondary Information: } \\
\hline \multirow[t]{7}{*}{ Order of Authors: } & Gregory MacMillan \\
\hline & Alan M Batterham \\
\hline & Paul Chesterton \\
\hline & Warren Gregson \\
\hline & Lorenzo Lolli \\
\hline & Matthew Weston \\
\hline & Greg Atkinson, PhD \\
\hline \multicolumn{2}{|c|}{ Order of Authors Secondary Information: } \\
\hline Author Comments: & $\begin{array}{l}\text { My co-authors and I would like this letter to the editor be considered for publication in } \\
\text { Sports Medicine. We feel as though it highlights the important issue of study quality } \\
\text { appraisal amongst the four systematic reviews now published on the acute chronic } \\
\text { workload ratio, two of which have been published in Sports Medicine }\end{array}$ \\
\hline Suggested Reviewers: & \\
\hline
\end{tabular}




\title{
Variability in the study quality appraisals reported in systematic reviews on the
} acute:chronic workload ratio and injury risk

\author{
Gregory MacMillan ${ }^{1}$, Alan M Batterham¹, Paul Chesterton ${ }^{1}$, Warren Gregson² Lorenzo Lolli², \\ Matthew Weston ${ }^{1}$ and Greg Atkinson ${ }^{1^{*}}$
}

\author{
${ }^{1}$ School of Health and Life Sciences, Teesside University, UK \\ ${ }^{2}$ Football Exchange, Research Institute of Sport Sciences, Liverpool John Moores University, UK \\ *Corresponding Author - greg.atkinson@tees.ac.uk
}

We welcome the recent systematic review by Andrade et al. [1], who explored in a detailed manner the question of whether the acute:chronic workload ratio (ACWR) is associated with risk of time- loss injury in professional team sports. Including their paper, there are now at least four systematic reviews published on this topic over the last two years [1-4]. Despite this number of evidence syntheses, we would like to highlight the worrying degree of inconsistency in conclusions between these reviews. While there are some differences between reviews in the selected study population, we question whether it is heterogeneity in the various appraisals of study quality that best explains the inconsistency in conclusions.

In Table 1, we present information on studied population, study quality appraisal details and the overall conclusions (derived primarily from the abstract and discussion sections) for each systematic review. Although a somewhat basic metric, we attempted to convert all the study quality ratings into percentage ratings, knowing the minimum and maximum number of items that were reported for each rating tool. In some reviews, quality scores were already reported as percentages. It can be seen that there is large variability between the average and range of percentage quality ratings in each review. Nevertheless, it can be seen that the review in which the most "negative" conclusion was arrived at [4] is also associated with the lowest average percentage rating across the studies. However, we also highlight that the quality tool employed by Wang et al. [4] also contained the least 
number of items. It is, however, striking how different the conclusions of Wang et al. [4] are, compared with those in the other reviews.

Quality ratings for individual studies were not reported by Maupin et al. [3]. Nevertheless, in Table 2, we present the individual study quality ratings for four studies that were included in the other systematic reviews. Again, the variability in study quality rating is striking, ranging from all items being realised (100\%) for one study [5] in one systematic review [2] to a very low quality rating for the same study in another systematic review [4]. It is also unclear in most systematic reviews whether a threshold quality rating was arrived at in an a priori manner to inform whether a particular study should be included or not. A priori decisions like this have been reported to be paramount for rating the stability and strength of evidence in systematic reviews [6].

In one review [3], an overall rating of 'fair' changed to 'good' when items deemed not to be relevant were removed from the quality tool that had already been modified. It can be seen that different study quality rating tools were used, as well as modified, by the various reviewers. Although the Downs and Black tool used in two reviews [1, 3] is designed to appraise the quality of randomised or non-randomised studies, the tool was designed specifically for intervention studies [7]. It is, therefore, not surprising that this tool needed to be modified by the researchers to appraise the quality of the various studies. The studies that have been reviewed are more akin to observational cohort studies rather than intervention studies, although there is also a within-subject change aspect to the ACWR exposure. Assuming that simple ratio assumptions are satisfied, the relevant question is whether a change (within players over time) in the ACWR is a useful predictive exposure for injury risk [8]. Validated tools for observational study designs are available, e.g., the National Institutes of Health Quality Assessment Tool for Observational Cohort and Cross-Sectional Studies [9]. We, therefore, suggest that a substantial source of variability that may have influenced the conclusions of some of the systematic reviews is the choice of the most appropriate study quality tool, and the amount and nature of modification that was deemed necessary to apply it to the relevant study designs. 
The replication of study findings is an increasingly important issue in research. From the evidence syntheses on the ACWR that have been published over the last two years, the conclusions seem to range from the ACWR metric being "valuable" to having serious "limitations" in terms of association to future injury risk. We congratulate Andrade and colleagues for appraising, in such a comprehensive manner, study quality, although their choice of measurement tool (designed for intervention studies) meant that substantial modifications were needed - as was the case for another review [3]. While several factors can influence discordance between systematic reviews [10], we maintain that variability between reviews in study quality tools, and how they are modified and interpreted are fundamental issues that may explain the variability in review conclusions on this particular topic. To arrive at a consistent and appropriate rating tool and threshold for acceptable study quality, we encourage researchers to collaborate on this matter.

\section{References}

1. Andrade, R., Wik, E.H., Rebelo-Marques, A. et al. Is the Acute: Chronic Workload Ratio (ACWR) Associated with Risk of Time-Loss Injury in Professional Team Sports? A Systematic Review of Methodology, Variables and Injury Risk in Practical Situations. Sports Med 2020; https://doi.org/10.1007/s40279-020-01308-6

2. Griffin, A., Kenny, I.C., Comyns, T.M. et al. The Association Between the Acute:Chronic Workload Ratio and Injury and its Application in Team Sports: A Systematic Review. Sports Med 2020; 50: 561-580.

3. Maupin D, Schram B, Canetti E, Orr R. The Relationship Between Acute: Chronic Workload Ratios and Injury Risk in Sports: A Systematic Review. Open Access J Sports Med. 2020; 11: $51-75$.

4. Wang A, Healy J, Hyett N, Berthelot G \& Okholm Kryger K. A systematic review on methodological variation in acute:chronic workload research in elite male football players, Sci Med Football 2020; DOI: 10.1080/24733938.2020.1765007 
5. Delecroix B, McCall A, Dawson B, Berthoin S, Dupont G. Workload and non-contact injury incidence in elite football players competing in European leagues. Eur J Sport Sci. 2018; 18(9):1280-1287.

6. Treadwell, J.R., Tregear, S.J., Reston, J.T. et al. A system for rating the stability and strength of medical evidence. BMC Med Res Methodol 2006; 6: 52

\section{https://doi.org/10.1186/1471-2288-6-52}

7. Downs SH, Black N. The feasibility of creating a checklist for the assessment of the methodological quality both of randomised and non-randomised studies of health care interventions. J Epidemiol Community Health. 1998; 52(6): 377-384.

8. Lolli L, Batterham AM, MacMillan G, Gregson W, Atkinson G. A Comment on "Does Mathematical Coupling Matter to the Acute to Chronic Workload Ratio? A Case Study from Elite Sport". Int J Sports Physiol Perform. 2020; 15(5): 600.

9. NIH (2014). National Institutes of Health Quality Assessment Tool for Observational Cohort and Cross-Sectional Studies. Available online at: https://www.nhlbi.nih.gov/healthpro/guidelines/in-develop/cardiovascular-risk-reduction/tools/cohort (Accessed: $30^{\text {th }}$ June, 2020)

10. Jadad AR, Cook DJ, Browman GP. A guide to interpreting discordant systematic reviews. CMAJ. 1997; 156(10): 1411-1416.

11. Jaspers A, Kuyvenhoven JP, Staes F, Frencken WGP, Helsen WF, Brink MS. Examination of the external and internal load indicators' association with overuse injuries in professional soccer players. J Sci Med Sport. 2018; 21(6): 579-85.

12. McCall A, Dupont G, Ekstrand J. Internal workload and noncontact injury: a one-season study of five teams from the UEFA Elite Club Injury Study. Br J Sports Med. 2018; 52(23): $1517-22$.

13. Malone S, Owen A, Newton M, Mendes B, Collins KD, Gabbett TJ. The acute: chonic workload ratio in relation to injury risk in professional soccer. J Sci Med Sport. 2017; 20(6): $561-5$. 


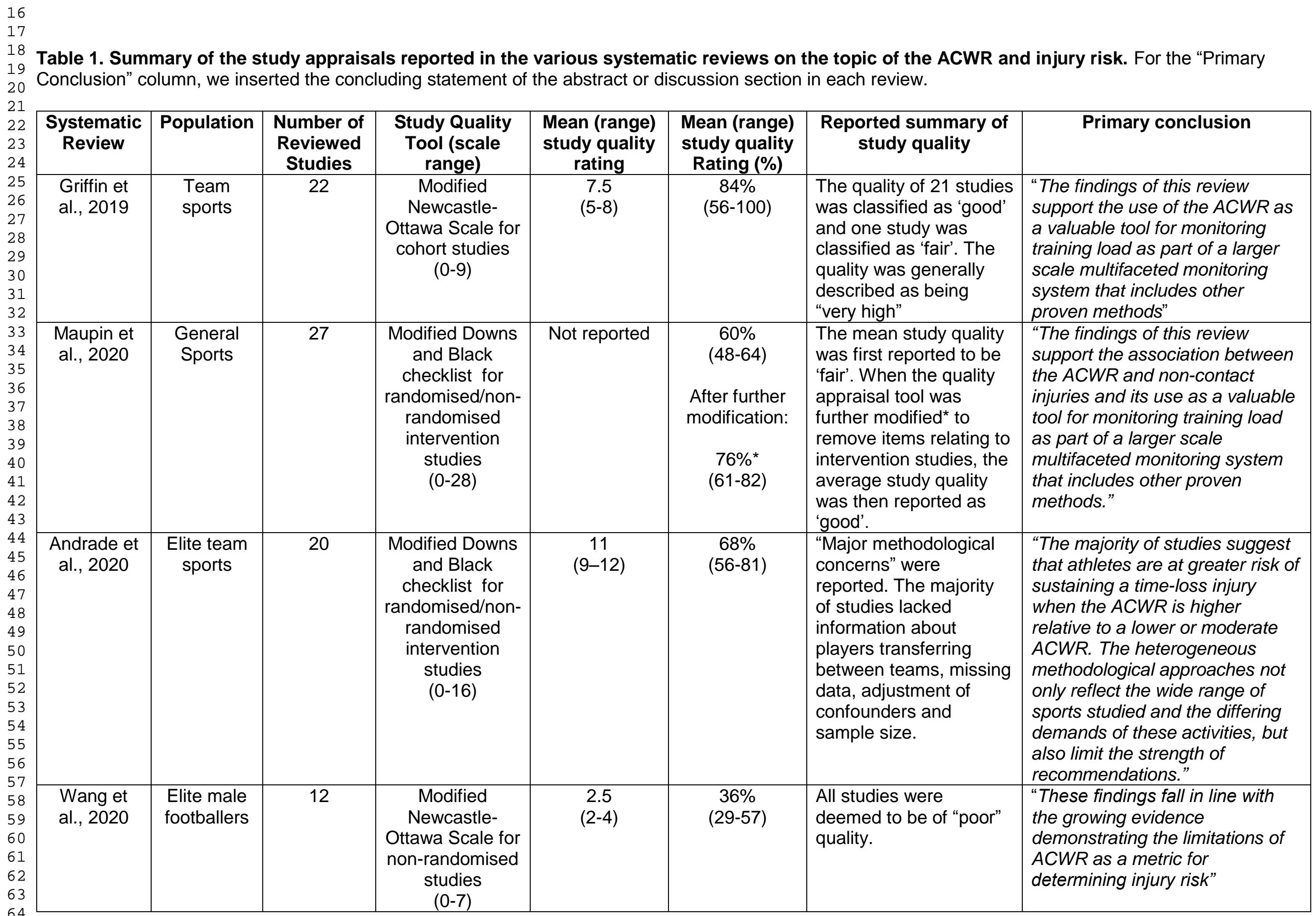


21 Table 2. Study quality ratings (\%) reported in the various systematic reviews for the four studies that were included in all reviews

\begin{tabular}{|l|c|c|c|}
\hline & Delecroix et al. [5] & Jaspers et al. [11] & McCall et al. [12] \\
\hline Griffin et al. [2] & 100 & 89 & 89 \\
\hline Andrade et al. [1] & 75 & 75 & 81 \\
\hline Wang et al. [4] & 43 & 29 & 57 \\
\hline Maupin et al. [3] & \multicolumn{3}{|c|}{ Quality appraisal for individual studies not reported } \\
\hline
\end{tabular}




\section{AUTHOR DECLARATION FORM}

At submission, EVERY AUTHOR listed in the manuscript must READ and COMPLETE the following statements on:

(A) Authorship Responsibility, (B) Authorship Criteria, (C) Authorship Contribution, (D) Funding Disclosures,

(E) Contributor Disclosures/Acknowledgments, and (F) Conflicts of Interest Disclosures.

It is important that you return this form as early as possible in the publication process. EVERY AUTHOR MUST COMPLETE AN INDIVIDUAL COPY OF THE FORM, AND EVERY SECTION OF THE FORM MUST BE COMPLETED. We will NOT consider your manuscript for publication until every author has completed the form and returned it to us.

Your name (please print): MATTHEW WESTON E-mail: M.Weston@tees.ac.uk

Journal name: Sports Medicine Corresponding author: Greg Atkinson

Manuscript title: Variability in the study quality appraisals reported in systematic reviews on the acute:chronic workload ratio and injury risk

\section{A. AUTHORSHIP RESPONSIBILITY}

$\triangle$ I certify that ALL of the following statements are correct (PLEASE CHECK THE BOX).

- The manuscript represents valid work; neither this manuscript nor one with substantially similar content under my authorship has been published or is being considered for publication elsewhere (except as described in the manuscript submission); and copies of any closely related manuscripts are enclosed in the manuscript submission; AND

- For manuscripts with more than one author, I agree to allow the corresponding author to serve as the primary correspondent with the editorial office and to review and sign off on the final proofs prior to publication; or, if I am the only author, I will be the corresponding author and agree to serve in the roles described above.

- For manuscripts that are a report of a study, I confirm that this work is an accurate representation of the trial results.

\section{B. AUTHORSHIP CRITERIA}

To fulfil all of the criteria for authorship, every author of the manuscript must have made substantial contributions to ALL of the following aspects of the work:

- Conception and planning of the work that led to the manuscript or acquisition, analysis and interpretation of the data, or both; $\boldsymbol{A N D}$

- Drafting and/or critical revision of the manuscript for important intellectual content; $\boldsymbol{A N D}$

- Approval of the final submitted version of the manuscript.

\ I certify that I fulfill ALL of the above criteria for authorship (PLEASE CHECK THE BOX).

\section{AUTHORSHIP CONTRIBUTION}

I certify that I have participated sufficiently in the work to take public responsibility for (PLEASE CHECK 1 OF THE 2 BOXES BELOW):

$\square$ Part of the content of the manuscript; OR

$\triangle$ The entire content of the manuscript.

\section{FUNDING DISCLOSURES}

\section{PLEASE CHECK 1 OF THE 2 BOXES BELOW:}

$\bigotimes$ I certify that no funding has been received for the conduct of this study and/or preparation of this manuscript; OR

$\square$ I certify that all financial and material support for the conduct of this study and/or preparation of this manuscript is clearly described in the Compliance with Ethical Standards section of the manuscript.

Some funding organizations require that authors of manuscripts reporting research deposit those manuscripts with an approved public repository.

Please check here if you have received such funding.

\section{E. CONTRIBUTOR DISCLOSURES}

All persons who have made substantial contributions to the work reported in the manuscript (e.g. data collection, data analysis, or writing or editing assistance) but who do not fulfill the authorship criteria MUST be named with their specific contributions in the Acknowledgments section of the manuscript. Groups of persons who have contributed may be listed under a heading such as 'Clinical investigators' and their function described. Because readers may infer their endorsement of the manuscript, all persons named in the Acknowledgments section MUST give the authors their written permission to be named in the manuscript.

$\bigotimes$ I certify that all persons who have made substantial contributions to this manuscript but who do not fulfill the authorship criteria are listed with their specific contributions in the Acknowledgments section in the manuscript, and that all persons named in the Acknowledgments section have given me written permission to be named in the manuscript. 


\section{F. CONFLICT OF INTEREST DISCLOSURES}

A conflict of interest exists when professional judgment concerning a primary interest (such as patients' welfare or the validity of research) may be influenced by a secondary interest (such as financial gain or personal rivalry). A conflict of interest may arise for authors when they have a financial interest that may influence - probably without their knowing their interpretation of their results or those of others. We believe that to make the best decision on how to deal with a manuscript we should know about any such conflict of interest that the authors may have. We are not aiming to eradicate conflicts of interests - they are almost inevitable. We will not reject manuscripts simply because the authors have a conflict of interest, but we will publish a declaration in the manuscript as to whether or not the authors have conflicts of interests.

All authors MUST complete the following checklist:

\begin{tabular}{|c|c|c|c|}
\hline $\begin{array}{l}\text { Category } \\
\text { of potential } \\
\text { conflict of } \\
\text { interest }\end{array}$ & $\begin{array}{l}\text { If you ha } \\
\text { subject } \\
\text { provide } \\
\text { When c } \\
\text { foreseed }\end{array}$ & $\begin{array}{l}\text { e had an } \\
\text { atter disc } \\
\text { tails. If y } \\
\text { opleting } t \\
\text { le future. }\end{array}$ & $\begin{array}{l}\text { entity that has a financial interest in the } \\
\text { eck the appropriate "Yes" box below and } \\
\text {, please check the appropriate "No" box. } \\
\text { th the last } 36 \text { months through to the }\end{array}$ \\
\hline & No $(\sqrt{ })$ & Yes $(\sqrt{ })$ & Details \\
\hline Employment & $\sqrt{ }$ & & \\
\hline $\begin{array}{l}\text { Grant received/grants } \\
\text { pending }\end{array}$ & $\sqrt{ }$ & & \\
\hline $\begin{array}{l}\text { Consulting fees or } \\
\text { honorarium }\end{array}$ & $\sqrt{ }$ & & \\
\hline $\begin{array}{l}\text { Support for travel to } \\
\text { meetings for the study, } \\
\text { manuscript preparation } \\
\text { or other purposes }\end{array}$ & $\sqrt{ }$ & & \\
\hline $\begin{array}{l}\text { Fees for participation in } \\
\text { review activities such } \\
\text { as data monitoring } \\
\text { boards, etc }\end{array}$ & $\sqrt{ }$ & & \\
\hline $\begin{array}{l}\text { Payment for writing or } \\
\text { reviewing the } \\
\text { manuscript }\end{array}$ & $\sqrt{ }$ & & \\
\hline $\begin{array}{l}\text { Provision of writing } \\
\text { assistance, medicines, } \\
\text { equipment or } \\
\text { administrative support }\end{array}$ & $\sqrt{ }$ & & \\
\hline $\begin{array}{l}\text { Payment for lectures } \\
\text { including service on } \\
\text { speakers bureaus }\end{array}$ & $\sqrt{ }$ & & \\
\hline Stock/stock options & $\sqrt{ }$ & & \\
\hline Expert testimony & $\sqrt{ }$ & & \\
\hline $\begin{array}{l}\text { Patents (planned, } \\
\text { pending or issued) }\end{array}$ & $\sqrt{ }$ & & \\
\hline Royalties & $\sqrt{ }$ & & \\
\hline $\begin{array}{l}\text { Other (err on the side } \\
\text { of full disclosure) }\end{array}$ & $\sqrt{ }$ & & \\
\hline
\end{tabular}


Every author MUST complete option 1 or option 2 as appropriate below. If you answered "Yes" to any of the questions relating to financial conflicts of interests in the table above (or if you wish to disclose a non-financial conflict of interest), you MUST write a suitable statement in the box below and include this statement in the Compliance with Ethical Standards section of the manuscript.

$\bigotimes$ I have no conflicts of interest to declare; OR

$\square$ The following statement regarding conflicts of interest and financial support for conduct of this study and/or preparation of this manuscript is to be published in the Compliance with Ethical Standards section of the manuscript:

Declaration: I certify that I have fully read and fully understood this form, and that the information that I have presented here is accurate and complete to the best of my knowledge.

Your name (please print): MATTHEW WESTON

Signature (please HAND-WRITE):

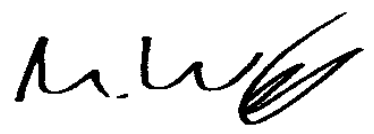

Date: $06 / 07 / 2020$ 


\section{AUTHOR DECLARATION FORM}

At submission, EVERY AUTHOR listed in the manuscript must READ and COMPLETE the following statements on:

(A) Authorship Responsibility, (B) Authorship Criteria, (C) Authorship Contribution, (D) Funding Disclosures,

(E) Contributor Disclosures/Acknowledgments, and $(F)$ Conflicts of interest Disclosures.

It is important that you retum this form as early as possible in the publication process. EVERY AUTHOR MUST COMPLETE AN INDIVIDUAL COPY OF THE FORM, AND EVERY SECTION OF THE FORM MUST BE COMPLETED. We will NOT consider your manuscript for publication until every author has completed the form and returned it to us.

Your name (please print): Paul Chesterton E-mail: p.chesterton@tees.ac.uk

Joumal name: Sports Medicine Corresponding author: Greg Atkinson

Manuscript title: Variability in the study quality appraisals reported in systematic reviews on the acute:chronic workload ration and injury risk

\section{A. AUTHORSHIP RESPONSIBILITY}

$\triangle$ I certify that ALL of the following statements are correct (PLEASE CHECK THE BOX).

- The manuscript represents valid work; neither this manuscript nor one with substantially similar content under my authorship has been published or is being considered for publication elsewhere (except as described in the manuscript submission); and copies of any closely related manuscripts are enclosed in the manuscript submission; AND

- For manuscripts with more than one author, I agree to allow the corresponding author to serve as the primary correspondent with the editorial office and to review and sign off on the final proofs prior to publication; or, if I am the only author, I will be the corresponding author and agree to serve in the roles described above.

- For manuscripts that are a report of a study, I confirm that this work is an accurate representation of the trial results.

\section{B. AUTHORSHIP CRITERIA}

To fulfil all of the criteria for authorship, every author of the manuscript must have made substantial contributions to ALL of the following aspects of the work:

- Conception and planning of the work that led to the manuscript or acquisition, analysis and interpretation of the data, or both; AND

- Drafting and/or critical revision of the manuscript for important intellectual content; AND

- Approval of the final submitted version of the manuscript.

$\triangle$ I certify that I fulfill ALL of the above criteria for authorship (PLEASE CHECK THE BOX).

\section{AUTHORSHIP CONTRIBUTION}

I certify that I have participated sufficiently in the work to take public responsibility for (PLEASE CHECK 1 OF THE 2 BOXES BELOW):

$\square$ Part of the content of the manuscript; OR

$\triangle$ The entire content of the manuscript.

\section{FUNDING DISCLOSURES}

\section{PLEASE CHECK 1 OF THE 2 BOXES BELOW:}

$\triangle$ I certify that no funding has been received for the conduct of this study and/or preparation of this manuscript; $O R$

I certify that all financial and material support for the conduct of this study and/or preparation of this manuscript is clearly described in the Compliance with Ethical Standards section of the manuscript.

Some funding organizations require that authors of manuscripts reporting research deposit those manuscripts with an approved public repository.

$\square$ Please check here if you have received such funding.

\section{E. CONTRIBUTOR DISCLOSURES}

All persons who have made substantial contributions to the work reported in the manuscript (e.g. data collection, data analysis, or writing or editing assistance) but who do not fulfill the authorship criteria MUST be named with their specific contributions in the Acknowledgments section of the manuscript. Groups of persons who have contributed may be listed under a heading such as 'Clinical investigators' and their function described. Because readers may infer their endorsement of the manuscript, all persons named in the Acknowledgments section MUST give the authors their written permission to be named in the manuscript.

\ I certify that all persons who have made substantial contributions to this manuscript but who do not fulfill the authorship criteria are listed with their specific contributions in the Acknowledgments section in the manuscript, and that all persons named in the Acknowledgments section have given me written permission to be named in the manuscript. 


\section{F. CONFLICT OF INTEREST DISCLOSURES}

A conflict of interest exists when professional judgment concerning a primary interest (such as patients' welfare or the validity of research) may be influenced by a secondary interest (such as financial gain or personal rivalry). A conflict of interest may arise for authors when they have a financial interest that may influence - probably without their knowing their interpretation of their results or those of others. We believe that to make the best decision on how to deal with a manuscript we should know about any such conflict of interest that the authors may have. We are not aiming to eradicate conflicts of interests - they are almost inevitable. We will not reject manuscripts simply because the authors have a conflict of interest, but we will publish a declaration in the manuscript as to whether or not the authors have conflicts of interests.

All authors MUST complete the following checklist:

\begin{tabular}{|c|c|c|c|}
\hline \multirow[t]{2}{*}{$\begin{array}{l}\text { Category } \\
\text { of potential } \\
\text { conflict of } \\
\text { interest }\end{array}$} & \multicolumn{3}{|c|}{$\begin{array}{l}\text { If you have had any of the listed relationships with an entity that has a financial interest in the } \\
\text { subject matter discussed in this manuscript, please check the appropriate "Yes" box below and } \\
\text { provide details. If you do not have a listed relationship, please check the appropriate "No" box. } \\
\text { When completing this section, please take into account the last } 36 \text { months through to the } \\
\text { foreseeable future. }\end{array}$} \\
\hline & No $(\sqrt{ })$ & $\operatorname{Yes}(\sqrt{ })$ & Details \\
\hline Employment & $\sqrt{ }$ & & \\
\hline $\begin{array}{l}\text { Grant received/grants } \\
\text { pending }\end{array}$ & $\sqrt{ }$ & & \\
\hline $\begin{array}{l}\text { Consulting fees or } \\
\text { honorarium }\end{array}$ & $\sqrt{ }$ & & \\
\hline $\begin{array}{l}\text { Support for travel to } \\
\text { meetings for the study, } \\
\text { manuscript preparation } \\
\text { or other purposes }\end{array}$ & $\sqrt{ }$ & & \\
\hline $\begin{array}{l}\text { Fees for participation in } \\
\text { review activities such } \\
\text { as data monitoring } \\
\text { boards, etc }\end{array}$ & $\sqrt{ }$ & & \\
\hline $\begin{array}{l}\text { Payment for writing or } \\
\text { reviewing the } \\
\text { manuscript }\end{array}$ & $\sqrt{ }$ & & \\
\hline $\begin{array}{l}\text { Provision of writing } \\
\text { assistance, medicines, } \\
\text { equipment or } \\
\text { administrative support }\end{array}$ & $\sqrt{ }$ & & \\
\hline $\begin{array}{l}\text { Payment for lectures } \\
\text { including service on } \\
\text { speakers bureaus }\end{array}$ & $\sqrt{ }$ & & \\
\hline Stock/stock options & $\sqrt{ }$ & & \\
\hline Expert testimony & $\sqrt{ }$ & & \\
\hline $\begin{array}{l}\text { Patents (planned, } \\
\text { pending or issued) }\end{array}$ & $\sqrt{ }$ & & \\
\hline Royalties & $\sqrt{ }$ & & \\
\hline $\begin{array}{l}\text { Other (err on the side } \\
\text { of full disclosure) }\end{array}$ & $\sqrt{ }$ & & \\
\hline
\end{tabular}


Every author MUST complete option 1 or option 2 as appropriate below. If you answered "Yes" to any of the questions relating to financial conflicts of interests in the table above (or if you wish to disclose a non-financial conflict of interest), you MUST write a suitable statement in the box below and include this statement in the Compliance with Ethical Standards section of the manuscript.

$\triangle$ I have no conflicts of interest to declare; $O R$

$\square$ The following statement regarding conflicts of interest and financial support for conduct of this study and/or preparation of this manuscript is to be published in the Compliance with Ethical Standards section of the manuscript:

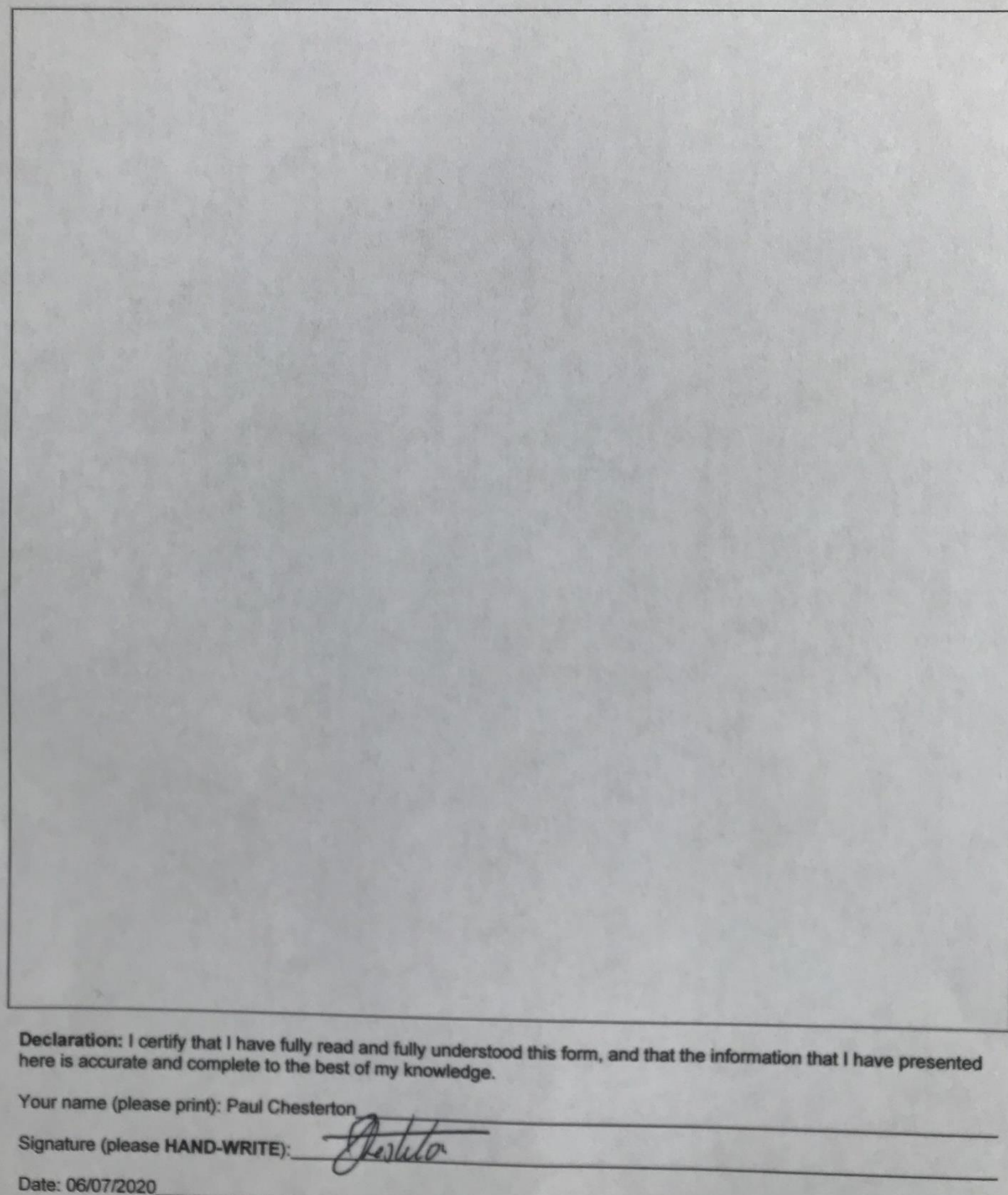

Date: 06/07/2020 


\section{AUTHOR DECLARATION FORM}

At submission, EVERY AUTHOR listed in the manuscript must READ and COMPLETE the following statements on:

(A) Authorship Responsibility, (B) Authorship Criteria, (C) Authorship Contribution, (D) Funding Disclosures,

(E) Contributor Disclosures/Acknowledgments, and (F) Conflicts of Interest Disclosures.

It is important that you return this form as early as possible in the publication process. EVERY AUTHOR MUST COMPLETE AN INDIVIDUAL COPY OF THE FORM, AND EVERY SECTION OF THE FORM MUST BE COMPLETED. We will NOT consider your manuscript for publication until every author has completed the form and returned it to us.

Your name (please print): GREGORY MACMILLAN E-mail: g.macmillan@tees.ac.uk

Journal name: Sports Medicine Corresponding author: Greg Atkinson

Manuscript title: Variability in the study quality appraisals reported in systematic reviews on the acute:chronic workload ratio and injury risk

\section{A. AUTHORSHIP RESPONSIBILITY}

$\triangle 1$ certify that ALL of the following statements are correct (PLEASE CHECK THE BOX).

- The manuscript represents valid work; neither this manuscript nor one with substantially similar content under my authorship has been published or is being considered for publication elsewhere (except as described in the manuscript submission); and copies of any closely related manuscripts are enclosed in the manuscript submission; AND

- For manuscripts with more than one author, I agree to allow the corresponding author to serve as the primary correspondent with the editorial office and to review and sign off on the final proofs prior to publication; or, if I am the only author, I will be the corresponding author and agree to serve in the roles described above.

- For manuscripts that are a report of a study, I confirm that this work is an accurate representation of the trial results.

\section{B. AUTHORSHIP CRITERIA}

To fulfil all of the criteria for authorship, every author of the manuscript must have made substantial contributions to ALL of the following aspects of the work:

- Conception and planning of the work that led to the manuscript or acquisition, analysis and interpretation of the data, or both; $\boldsymbol{A N D}$

- Drafting and/or critical revision of the manuscript for important intellectual content; $\boldsymbol{A N D}$

- Approval of the final submitted version of the manuscript.

\ I certify that I fulfill ALL of the above criteria for authorship (PLEASE CHECK THE BOX).

\section{AUTHORSHIP CONTRIBUTION}

I certify that I have participated sufficiently in the work to take public responsibility for (PLEASE CHECK 1 OF THE 2 BOXES BELOW):

$\square$ Part of the content of the manuscript; $O R$

$\triangle$ The entire content of the manuscript.

\section{FUNDING DISCLOSURES}

\section{PLEASE CHECK 1 OF THE 2 BOXES BELOW:}

$\bigotimes$ I certify that no funding has been received for the conduct of this study and/or preparation of this manuscript; OR

$\square$ I certify that all financial and material support for the conduct of this study and/or preparation of this manuscript is clearly described in the Compliance with Ethical Standards section of the manuscript.

Some funding organizations require that authors of manuscripts reporting research deposit those manuscripts with an approved public repository.

Please check here if you have received such funding.

\section{E. CONTRIBUTOR DISCLOSURES}

All persons who have made substantial contributions to the work reported in the manuscript (e.g. data collection, data analysis, or writing or editing assistance) but who do not fulfill the authorship criteria MUST be named with their specific contributions in the Acknowledgments section of the manuscript. Groups of persons who have contributed may be listed under a heading such as 'Clinical investigators' and their function described. Because readers may infer their endorsement of the manuscript, all persons named in the Acknowledgments section MUST give the authors their written permission to be named in the manuscript.

$\triangle I$ certify that all persons who have made substantial contributions to this manuscript but who do not fulfill the authorship criteria are listed with their specific contributions in the Acknowledgments section in the manuscript, and that all persons named in the Acknowledgments section have given me written permission to be named in the manuscript. 


\section{F. CONFLICT OF INTEREST DISCLOSURES}

A conflict of interest exists when professional judgment concerning a primary interest (such as patients' welfare or the validity of research) may be influenced by a secondary interest (such as financial gain or personal rivalry). A conflict of interest may arise for authors when they have a financial interest that may influence - probably without their knowing their interpretation of their results or those of others. We believe that to make the best decision on how to deal with a manuscript we should know about any such conflict of interest that the authors may have. We are not aiming to eradicate conflicts of interests - they are almost inevitable. We will not reject manuscripts simply because the authors have a conflict of interest, but we will publish a declaration in the manuscript as to whether or not the authors have conflicts of interests.

All authors MUST complete the following checklist:

\begin{tabular}{|c|c|c|c|}
\hline $\begin{array}{l}\text { Category } \\
\text { of potential } \\
\text { conflict of } \\
\text { interest }\end{array}$ & $\begin{array}{l}\text { If you he } \\
\text { subject } \\
\text { provide } \\
\text { When c } \\
\text { foreseec }\end{array}$ & $\begin{array}{l}\text { e had an } \\
\text { atter disc } \\
\text { tails. If y } \\
\text { apleting } t \\
\text { le future. }\end{array}$ & $\begin{array}{l}\text { entity that has a financial interest in the } \\
\text { eck the appropriate "Yes" box below and } \\
\text {, please check the appropriate "No" box. } \\
\text { th the last } 36 \text { months through to the }\end{array}$ \\
\hline & No $(\sqrt{ })$ & Yes $(\sqrt{ })$ & Details \\
\hline Employment & $\sqrt{ }$ & & \\
\hline $\begin{array}{l}\text { Grant received/grants } \\
\text { pending }\end{array}$ & $\sqrt{ }$ & & \\
\hline $\begin{array}{l}\text { Consulting fees or } \\
\text { honorarium }\end{array}$ & $\sqrt{ }$ & & \\
\hline $\begin{array}{l}\text { Support for travel to } \\
\text { meetings for the study, } \\
\text { manuscript preparation } \\
\text { or other purposes }\end{array}$ & $\sqrt{ }$ & & \\
\hline $\begin{array}{l}\text { Fees for participation in } \\
\text { review activities such } \\
\text { as data monitoring } \\
\text { boards, etc }\end{array}$ & $\sqrt{ }$ & & \\
\hline $\begin{array}{l}\text { Payment for writing or } \\
\text { reviewing the } \\
\text { manuscript }\end{array}$ & $\sqrt{ }$ & & \\
\hline $\begin{array}{l}\text { Provision of writing } \\
\text { assistance, medicines, } \\
\text { equipment or } \\
\text { administrative support }\end{array}$ & $\sqrt{ }$ & & \\
\hline $\begin{array}{l}\text { Payment for lectures } \\
\text { including service on } \\
\text { speakers bureaus }\end{array}$ & $\sqrt{ }$ & & \\
\hline Stock/stock options & $\sqrt{ }$ & & \\
\hline Expert testimony & $\sqrt{ }$ & & \\
\hline $\begin{array}{l}\text { Patents (planned, } \\
\text { pending or issued) }\end{array}$ & $\sqrt{ }$ & & \\
\hline Royalties & $\sqrt{ }$ & & \\
\hline $\begin{array}{l}\text { Other (err on the side } \\
\text { of full disclosure) }\end{array}$ & $\sqrt{ }$ & & \\
\hline
\end{tabular}


Every author MUST complete option 1 or option 2 as appropriate below. If you answered "Yes" to any of the questions relating to financial conflicts of interests in the table above (or if you wish to disclose a non-financial conflict of interest), you MUST write a suitable statement in the box below and include this statement in the Compliance with Ethical Standards section of the manuscript.

$\bigotimes$ I have no conflicts of interest to declare; OR

$\square$ The following statement regarding conflicts of interest and financial support for conduct of this study and/or preparation of this manuscript is to be published in the Compliance with Ethical Standards section of the manuscript:

Declaration: I certify that I have fully read and fully understood this form, and that the information that I have presented here is accurate and complete to the best of my knowledge.

Your name (please print): GREGORY MACMILLAN

Signature (please HAND-WRITE)

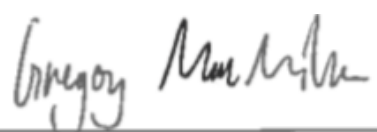

Date: $06 / 07 / 2020$ 


\section{AUTHOR DECLARATION FORM}

At submission, EVERY AUTHOR listed in the manuscript must READ and COMPLETE the following statements on:

(A) Authorship Responsibility, (B) Authorship Criteria, (C) Authorship Contribution, (D) Funding Disclosures,

(E) Contributor Disclosures/Acknowledgments, and (F) Conflicts of Interest Disclosures.

It is important that you return this form as early as possible in the publication process. EVERY AUTHOR MUST COMPLETE AN INDIVIDUAL COPY OF THE FORM, AND EVERY SECTION OF THE FORM MUST BE COMPLETED. We will NOT consider your manuscript for publication until every author has completed the form and returned it to us.

Your name (please print): Greg Atkinson E-mail: greg.atkinson@tees.ac.uk

Journal name: Sports Medicine Corresponding author: Greg Atkinson

Manuscript title: Variability in the study quality appraisals reported in systematic reviews on the acute:chronic workload ratio and injury risk

\section{A. AUTHORSHIP RESPONSIBILITY}

$\triangle$ I certify that ALL of the following statements are correct (PLEASE CHECK THE BOX).

- The manuscript represents valid work; neither this manuscript nor one with substantially similar content under my authorship has been published or is being considered for publication elsewhere (except as described in the manuscript submission); and copies of any closely related manuscripts are enclosed in the manuscript submission; AND

- For manuscripts with more than one author, I agree to allow the corresponding author to serve as the primary correspondent with the editorial office and to review and sign off on the final proofs prior to publication; or, if I am the only author, I will be the corresponding author and agree to serve in the roles described above.

- For manuscripts that are a report of a study, I confirm that this work is an accurate representation of the trial results.

\section{B. AUTHORSHIP CRITERIA}

To fulfil all of the criteria for authorship, every author of the manuscript must have made substantial contributions to ALL of the following aspects of the work:

- Conception and planning of the work that led to the manuscript or acquisition, analysis and interpretation of the data, or both; $\boldsymbol{A N D}$

- Drafting and/or critical revision of the manuscript for important intellectual content; $\boldsymbol{A N D}$

- Approval of the final submitted version of the manuscript.

$\bigotimes$ I certify that I fulfill ALL of the above criteria for authorship (PLEASE CHECK THE BOX).

\section{AUTHORSHIP CONTRIBUTION}

I certify that I have participated sufficiently in the work to take public responsibility for (PLEASE CHECK 1 OF THE 2 BOXES BELOW):

$\square$ Part of the content of the manuscript; $O R$

$\triangle$ The entire content of the manuscript.

\section{FUNDING DISCLOSURES}

\section{PLEASE CHECK 1 OF THE 2 BOXES BELOW:}

$\bigotimes$ I certify that no funding has been received for the conduct of this study and/or preparation of this manuscript; OR

$\square$ I certify that all financial and material support for the conduct of this study and/or preparation of this manuscript is clearly described in the Compliance with Ethical Standards section of the manuscript.

Some funding organizations require that authors of manuscripts reporting research deposit those manuscripts with an approved public repository.

Please check here if you have received such funding.

\section{E. CONTRIBUTOR DISCLOSURES}

All persons who have made substantial contributions to the work reported in the manuscript (e.g. data collection, data analysis, or writing or editing assistance) but who do not fulfill the authorship criteria MUST be named with their specific contributions in the Acknowledgments section of the manuscript. Groups of persons who have contributed may be listed under a heading such as 'Clinical investigators' and their function described. Because readers may infer their endorsement of the manuscript, all persons named in the Acknowledgments section MUST give the authors their written permission to be named in the manuscript.

$\triangle I$ certify that all persons who have made substantial contributions to this manuscript but who do not fulfill the authorship criteria are listed with their specific contributions in the Acknowledgments section in the manuscript, and that all persons named in the Acknowledgments section have given me written permission to be named in the manuscript. 


\section{F. CONFLICT OF INTEREST DISCLOSURES}

A conflict of interest exists when professional judgment concerning a primary interest (such as patients' welfare or the validity of research) may be influenced by a secondary interest (such as financial gain or personal rivalry). A conflict of interest may arise for authors when they have a financial interest that may influence - probably without their knowing their interpretation of their results or those of others. We believe that to make the best decision on how to deal with a manuscript we should know about any such conflict of interest that the authors may have. We are not aiming to eradicate conflicts of interests - they are almost inevitable. We will not reject manuscripts simply because the authors have a conflict of interest, but we will publish a declaration in the manuscript as to whether or not the authors have conflicts of interests.

All authors MUST complete the following checklist:

\begin{tabular}{|c|c|c|c|}
\hline \multirow[t]{2}{*}{$\begin{array}{l}\text { Category } \\
\text { of potential } \\
\text { conflict of } \\
\text { interest }\end{array}$} & \multicolumn{3}{|c|}{$\begin{array}{l}\text { If you have had any of the listed relationships with an entity that has a financial interest in the } \\
\text { subject matter discussed in this manuscript, please check the appropriate "Yes" box below and } \\
\text { provide details. If you do not have a listed relationship, please check the appropriate "No" box. } \\
\text { When completing this section, please take into account the last } 36 \text { months through to the } \\
\text { foreseeable future. }\end{array}$} \\
\hline & No $(\sqrt{ })$ & Yes $(\sqrt{ })$ & Details \\
\hline Employment & $x$ & & \\
\hline $\begin{array}{l}\text { Grant received/grants } \\
\text { pending }\end{array}$ & $x$ & & \\
\hline $\begin{array}{l}\text { Consulting fees or } \\
\text { honorarium }\end{array}$ & $X$ & & \\
\hline $\begin{array}{l}\text { Support for travel to } \\
\text { meetings for the study, } \\
\text { manuscript preparation } \\
\text { or other purposes }\end{array}$ & $x$ & & \\
\hline $\begin{array}{l}\text { Fees for participation in } \\
\text { review activities such } \\
\text { as data monitoring } \\
\text { boards, etc }\end{array}$ & $x$ & & \\
\hline $\begin{array}{l}\text { Payment for writing or } \\
\text { reviewing the } \\
\text { manuscript }\end{array}$ & $x$ & & \\
\hline $\begin{array}{l}\text { Provision of writing } \\
\text { assistance, medicines, } \\
\text { equipment or } \\
\text { administrative support }\end{array}$ & $X$ & & \\
\hline $\begin{array}{l}\text { Payment for lectures } \\
\text { including service on } \\
\text { speakers bureaus }\end{array}$ & $X$ & & \\
\hline Stock/stock options & $x$ & & \\
\hline Expert testimony & $X$ & & \\
\hline $\begin{array}{l}\text { Patents (planned, } \\
\text { pending or issued) }\end{array}$ & $X$ & & \\
\hline Royalties & $X$ & & \\
\hline $\begin{array}{l}\text { Other (err on the side } \\
\text { of full disclosure) }\end{array}$ & $x$ & & \\
\hline
\end{tabular}


Every author MUST complete option 1 or option 2 as appropriate below. If you answered "Yes" to any of the questions relating to financial conflicts of interests in the table above (or if you wish to disclose a non-financial conflict of interest), you MUST write a suitable statement in the box below and include this statement in the Compliance with Ethical Standards section of the manuscript.

$\bigotimes$ I have no conflicts of interest to declare; OR

$\square$ The following statement regarding conflicts of interest and financial support for conduct of this study and/or preparation of this manuscript is to be published in the Compliance with Ethical Standards section of the manuscript:

Declaration: I certify that I have fully read and fully understood this form, and that the information that I have presented here is accurate and complete to the best of my knowledge.

Your name (please print): GREG ATKINSON

Signature (please HAND-WRITE):

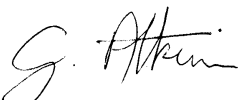

Date: $6^{\text {th }}$ July, 2020 



\section{AUTHOR DECLARATION FORM}

At submission, EVERY AUTHOR listed in the manuscript must READ and COMPLETE the following statements on:

(A) Authorship Responsibility, (B) Authorship Criteria, (C) Authorship Contribution, (D) Funding Disclosures,

(E) Contributor Disclosures/Acknowledgments, and (F) Conflicts of Interest Disclosures.

It is important that you return this form as early as possible in the publication process. EVERY AUTHOR MUST COMPLETE AN INDIVIDUAL COPY OF THE FORM, AND EVERY SECTION OF THE FORM MUST BE COMPLETED. We will NOT consider your manuscript for publication until every author has completed the form and returned it to us.

Your name (please print): Alan Mark Batterham E-mail: a.batterham@tees.ac.uk

Journal name: Sports Medicine Corresponding author: Greg Atkinson

Manuscript title: Variability in the study quality appraisals reported in systematic reviews on the acute: chronic workload ratio and injury risk

\section{A. AUTHORSHIP RESPONSIBILITY}

$\triangle$ I certify that ALL of the following statements are correct (PLEASE CHECK THE BOX).

- The manuscript represents valid work; neither this manuscript nor one with substantially similar content under my authorship has been published or is being considered for publication elsewhere (except as described in the manuscript submission); and copies of any closely related manuscripts are enclosed in the manuscript submission; AND

- For manuscripts with more than one author, I agree to allow the corresponding author to serve as the primary correspondent with the editorial office and to review and sign off on the final proofs prior to publication; or, if I am the only author, I will be the corresponding author and agree to serve in the roles described above.

- For manuscripts that are a report of a study, I confirm that this work is an accurate representation of the trial results.

\section{B. AUTHORSHIP CRITERIA}

To fulfil all of the criteria for authorship, every author of the manuscript must have made substantial contributions to ALL of the following aspects of the work:

- Conception and planning of the work that led to the manuscript or acquisition, analysis and interpretation of the data, or both; $\boldsymbol{A N D}$

- Drafting and/or critical revision of the manuscript for important intellectual content; $\boldsymbol{A N D}$

- Approval of the final submitted version of the manuscript.

$\triangle$ I certify that I fulfill ALL of the above criteria for authorship (PLEASE CHECK THE BOX).

\section{AUTHORSHIP CONTRIBUTION}

I certify that I have participated sufficiently in the work to take public responsibility for (PLEASE CHECK 1 OF THE 2 BOXES BELOW):

$\square$ Part of the content of the manuscript; $\boldsymbol{O R}$

$\triangle$ The entire content of the manuscript.

\section{FUNDING DISCLOSURES}

\section{PLEASE CHECK 1 OF THE 2 BOXES BELOW:}

$\triangle I$ certify that no funding has been received for the conduct of this study and/or preparation of this manuscript; $O R$

$\square$ I certify that all financial and material support for the conduct of this study and/or preparation of this manuscript is clearly described in the Compliance with Ethical Standards section of the manuscript.

Some funding organizations require that authors of manuscripts reporting research deposit those manuscripts with an approved public repository.

$\square$ Please check here if you have received such funding.

\section{E. CONTRIBUTOR DISCLOSURES}

All persons who have made substantial contributions to the work reported in the manuscript (e.g. data collection, data analysis, or writing or editing assistance) but who do not fulfill the authorship criteria MUST be named with their specific contributions in the Acknowledgments section of the manuscript. Groups of persons who have contributed may be listed under a heading such as 'Clinical investigators' and their function described. Because readers may infer their endorsement of the manuscript, all persons named in the Acknowledgments section MUST give the authors their written permission to be named in the manuscript.

\I certify that all persons who have made substantial contributions to this manuscript but who do not fulfill the authorship criteria are listed with their specific contributions in the Acknowledgments section in the manuscript, and that all persons named in the Acknowledgments section have given me written permission to be named in the manuscript. 


\section{F. CONFLICT OF INTEREST DISCLOSURES}

A conflict of interest exists when professional judgment concerning a primary interest (such as patients' welfare or the validity of research) may be influenced by a secondary interest (such as financial gain or personal rivalry). A conflict of interest may arise for authors when they have a financial interest that may influence - probably without their knowing their interpretation of their results or those of others. We believe that to make the best decision on how to deal with a manuscript we should know about any such conflict of interest that the authors may have. We are not aiming to eradicate conflicts of interests - they are almost inevitable. We will not reject manuscripts simply because the authors have a conflict of interest, but we will publish a declaration in the manuscript as to whether or not the authors have conflicts of interests.

All authors MUST complete the following checklist:

\begin{tabular}{|c|c|c|c|}
\hline $\begin{array}{l}\text { Category } \\
\text { of potential } \\
\text { conflict of } \\
\text { interest }\end{array}$ & $\begin{array}{l}\text { If you ha } \\
\text { subject } \\
\text { provide } \\
\text { When c } \\
\text { foreseed }\end{array}$ & $\begin{array}{l}\text { a had an } \\
\text { atter disc } \\
\text { tails. If y } \\
\text { apleting } t \\
\text { le future. }\end{array}$ & $\begin{array}{l}\text { entity that has a financial interest in the } \\
\text { leck the appropriate "Yes" box below and } \\
\text {, please check the appropriate "No" box. } \\
\text { the last } 36 \text { months through to the }\end{array}$ \\
\hline & No $(\sqrt{ })$ & Yes $(\sqrt{ })$ & Details \\
\hline Employment & $\checkmark$ & & \\
\hline $\begin{array}{l}\text { Grant received/grants } \\
\text { pending }\end{array}$ & $\checkmark$ & & \\
\hline $\begin{array}{l}\text { Consulting fees or } \\
\text { honorarium }\end{array}$ & $\checkmark$ & & \\
\hline $\begin{array}{l}\text { Support for travel to } \\
\text { meetings for the study, } \\
\text { manuscript preparation } \\
\text { or other purposes }\end{array}$ & $\checkmark$ & & \\
\hline $\begin{array}{l}\text { Fees for participation in } \\
\text { review activities such } \\
\text { as data monitoring } \\
\text { boards, etc }\end{array}$ & $\checkmark$ & & \\
\hline $\begin{array}{l}\text { Payment for writing or } \\
\text { reviewing the } \\
\text { manuscript }\end{array}$ & $\checkmark$ & & \\
\hline $\begin{array}{l}\text { Provision of writing } \\
\text { assistance, medicines, } \\
\text { equipment or } \\
\text { administrative support }\end{array}$ & $\checkmark$ & & \\
\hline $\begin{array}{l}\text { Payment for lectures } \\
\text { including service on } \\
\text { speakers bureaus }\end{array}$ & $\checkmark$ & & \\
\hline Stock/stock options & $\checkmark$ & & \\
\hline Expert testimony & $\checkmark$ & & \\
\hline $\begin{array}{l}\text { Patents (planned, } \\
\text { pending or issued) }\end{array}$ & $\checkmark$ & & \\
\hline Royalties & $\checkmark$ & & \\
\hline $\begin{array}{l}\text { Other (err on the side } \\
\text { of full disclosure) }\end{array}$ & $\checkmark$ & & \\
\hline
\end{tabular}


Every author MUST complete option 1 or option 2 as appropriate below. If you answered "Yes" to any of the questions relating to financial conflicts of interests in the table above (or if you wish to disclose a non-financial conflict of interest), you MUST write a suitable statement in the box below and include this statement in the Compliance with Ethical Standards section of the manuscript.

$\bigotimes$ I have no conflicts of interest to declare; OR

$\square$ The following statement regarding conflicts of interest and financial support for conduct of this study and/or preparation of this manuscript is to be published in the Compliance with Ethical Standards section of the manuscript:

Declaration: I certify that I have fully read and fully understood this form, and that the information that I have presented here is accurate and complete to the best of my knowledge.

Your name (please print): Alan Mark Batterham

Signature (please HAND-WRITE):

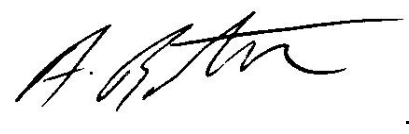

Date: 6 July 2020 


\section{AUTHOR DECLARATION FORM}

At submission, EVERY AUTHOR listed in the manuscript must READ and COMPLETE the following statements on:

(A) Authorship Responsibility, (B) Authorship Criteria, (C) Authorship Contribution, (D) Funding Disclosures,

(E) Contributor Disclosures/Acknowledgments, and (F) Conflicts of Interest Disclosures.

It is important that you return this form as early as possible in the publication process. EVERY AUTHOR MUST COMPLETE AN INDIVIDUAL COPY OF THE FORM, AND EVERY SECTION OF THE FORM MUST BE COMPLETED. We will NOT consider your manuscript for publication until every author has completed the form and returned it to us.

Your name (please print): WARREN GREGSON E-mail:W.gregson@ljmu.ac.uk

Journal name: Sports Medicine Corresponding author: Greg Atkinson

Manuscript title: Variability in the study quality appraisals reported in systematic reviews on the acute:chronic workload ratio and injury risk

\section{A. AUTHORSHIP RESPONSIBILITY}

$\triangle$ I certify that ALL of the following statements are correct (PLEASE CHECK THE BOX).

- The manuscript represents valid work; neither this manuscript nor one with substantially similar content under my authorship has been published or is being considered for publication elsewhere (except as described in the manuscript submission); and copies of any closely related manuscripts are enclosed in the manuscript submission; AND

- For manuscripts with more than one author, I agree to allow the corresponding author to serve as the primary correspondent with the editorial office and to review and sign off on the final proofs prior to publication; or, if I am the only author, I will be the corresponding author and agree to serve in the roles described above.

- For manuscripts that are a report of a study, I confirm that this work is an accurate representation of the trial results.

\section{B. AUTHORSHIP CRITERIA}

To fulfil all of the criteria for authorship, every author of the manuscript must have made substantial contributions to ALL of the following aspects of the work:

- Conception and planning of the work that led to the manuscript or acquisition, analysis and interpretation of the data, or both; $\boldsymbol{A N D}$

- Drafting and/or critical revision of the manuscript for important intellectual content; $\boldsymbol{A N D}$

- Approval of the final submitted version of the manuscript.

$\bigotimes$ I certify that I fulfill ALL of the above criteria for authorship (PLEASE CHECK THE BOX).

\section{AUTHORSHIP CONTRIBUTION}

I certify that I have participated sufficiently in the work to take public responsibility for (PLEASE CHECK 1 OF THE 2 BOXES BELOW):

$\square$ Part of the content of the manuscript; OR

$\triangle$ The entire content of the manuscript.

\section{FUNDING DISCLOSURES}

\section{PLEASE CHECK 1 OF THE 2 BOXES BELOW:}

$\bigotimes$ I certify that no funding has been received for the conduct of this study and/or preparation of this manuscript; OR

$\square$ I certify that all financial and material support for the conduct of this study and/or preparation of this manuscript is clearly described in the Compliance with Ethical Standards section of the manuscript.

Some funding organizations require that authors of manuscripts reporting research deposit those manuscripts with an approved public repository.

Please check here if you have received such funding.

\section{E. CONTRIBUTOR DISCLOSURES}

All persons who have made substantial contributions to the work reported in the manuscript (e.g. data collection, data analysis, or writing or editing assistance) but who do not fulfill the authorship criteria MUST be named with their specific contributions in the Acknowledgments section of the manuscript. Groups of persons who have contributed may be listed under a heading such as 'Clinical investigators' and their function described. Because readers may infer their endorsement of the manuscript, all persons named in the Acknowledgments section MUST give the authors their written permission to be named in the manuscript.

$\bigotimes$ I certify that all persons who have made substantial contributions to this manuscript but who do not fulfill the authorship criteria are listed with their specific contributions in the Acknowledgments section in the manuscript, and that all persons named in the Acknowledgments section have given me written permission to be named in the manuscript. 


\section{F. CONFLICT OF INTEREST DISCLOSURES}

A conflict of interest exists when professional judgment concerning a primary interest (such as patients' welfare or the validity of research) may be influenced by a secondary interest (such as financial gain or personal rivalry). A conflict of interest may arise for authors when they have a financial interest that may influence - probably without their knowing their interpretation of their results or those of others. We believe that to make the best decision on how to deal with a manuscript we should know about any such conflict of interest that the authors may have. We are not aiming to eradicate conflicts of interests - they are almost inevitable. We will not reject manuscripts simply because the authors have a conflict of interest, but we will publish a declaration in the manuscript as to whether or not the authors have conflicts of interests.

All authors MUST complete the following checklist:

\begin{tabular}{|c|c|c|c|}
\hline $\begin{array}{l}\text { Category } \\
\text { of potential } \\
\text { conflict of } \\
\text { interest }\end{array}$ & $\begin{array}{l}\text { If you he } \\
\text { subject } \\
\text { provide } \\
\text { When c } \\
\text { foreseec }\end{array}$ & $\begin{array}{l}\text { e had an } \\
\text { atter disc } \\
\text { tails. If y } \\
\text { apleting } t \\
\text { le future. }\end{array}$ & $\begin{array}{l}\text { entity that has a financial interest in the } \\
\text { eck the appropriate "Yes" box below and } \\
\text {, please check the appropriate "No" box. } \\
\text { th the last } 36 \text { months through to the }\end{array}$ \\
\hline & No $(\sqrt{ })$ & Yes $(\sqrt{ })$ & Details \\
\hline Employment & $\sqrt{ }$ & & \\
\hline $\begin{array}{l}\text { Grant received/grants } \\
\text { pending }\end{array}$ & $\sqrt{ }$ & & \\
\hline $\begin{array}{l}\text { Consulting fees or } \\
\text { honorarium }\end{array}$ & $\sqrt{ }$ & & \\
\hline $\begin{array}{l}\text { Support for travel to } \\
\text { meetings for the study, } \\
\text { manuscript preparation } \\
\text { or other purposes }\end{array}$ & $\sqrt{ }$ & & \\
\hline $\begin{array}{l}\text { Fees for participation in } \\
\text { review activities such } \\
\text { as data monitoring } \\
\text { boards, etc }\end{array}$ & $\sqrt{ }$ & & \\
\hline $\begin{array}{l}\text { Payment for writing or } \\
\text { reviewing the } \\
\text { manuscript }\end{array}$ & $\sqrt{ }$ & & \\
\hline $\begin{array}{l}\text { Provision of writing } \\
\text { assistance, medicines, } \\
\text { equipment or } \\
\text { administrative support }\end{array}$ & $\sqrt{ }$ & & \\
\hline $\begin{array}{l}\text { Payment for lectures } \\
\text { including service on } \\
\text { speakers bureaus }\end{array}$ & $\sqrt{ }$ & & \\
\hline Stock/stock options & $\sqrt{ }$ & & \\
\hline Expert testimony & $\sqrt{ }$ & & \\
\hline $\begin{array}{l}\text { Patents (planned, } \\
\text { pending or issued) }\end{array}$ & $\sqrt{ }$ & & \\
\hline Royalties & $\sqrt{ }$ & & \\
\hline $\begin{array}{l}\text { Other (err on the side } \\
\text { of full disclosure) }\end{array}$ & $\sqrt{ }$ & & \\
\hline
\end{tabular}


Every author MUST complete option 1 or option 2 as appropriate below. If you answered "Yes" to any of the questions relating to financial conflicts of interests in the table above (or if you wish to disclose a non-financial conflict of interest), you MUST write a suitable statement in the box below and include this statement in the Compliance with Ethical Standards section of the manuscript.

$\bigotimes$ I have no conflicts of interest to declare; OR

$\square$ The following statement regarding conflicts of interest and financial support for conduct of this study and/or preparation of this manuscript is to be published in the Compliance with Ethical Standards section of the manuscript:

Declaration: I certify that I have fully read and fully understood this form, and that the information that I have presented here is accurate and complete to the best of my knowledge.

Your name (please print):WARREN GREGSON

Signature (please HAND-WRITE):

Date:6/7/2020 



\section{AUTHOR DECLARATION FORM}

At submission, EVERY AUTHOR listed in the manuscript must READ and COMPLETE the following statements on:

(A) Authorship Responsibility, (B) Authorship Criteria, (C) Authorship Contribution, (D) Funding Disclosures,

(E) Contributor Disclosures/Acknowledgments, and (F) Conflicts of Interest Disclosures.

It is important that you return this form as early as possible in the publication process. EVERY AUTHOR MUST COMPLETE AN INDIVIDUAL COPY OF THE FORM, AND EVERY SECTION OF THE FORM MUST BE COMPLETED. We will NOT consider your manuscript for publication until every author has completed the form and returned it to us.

Your name (please print): Lorenzo Lolli E-mail: lollilorenzo0@gmail.com

Journal name: Sports Medicine

Corresponding author: Greg Atkinson

Manuscript title: Variability in the study quality appraisals reported in systematic reviews on the acute:chronic workload ratio and injury risk

\section{A. AUTHORSHIP RESPONSIBILITY}

$\triangle$ I certify that ALL of the following statements are correct (PLEASE CHECK THE BOX).

- The manuscript represents valid work; neither this manuscript nor one with substantially similar content under my authorship has been published or is being considered for publication elsewhere (except as described in the manuscript submission); and copies of any closely related manuscripts are enclosed in the manuscript submission; AND

- For manuscripts with more than one author, I agree to allow the corresponding author to serve as the primary correspondent with the editorial office and to review and sign off on the final proofs prior to publication; or, if I am the only author, I will be the corresponding author and agree to serve in the roles described above.

- For manuscripts that are a report of a study, I confirm that this work is an accurate representation of the trial results.

\section{B. AUTHORSHIP CRITERIA}

To fulfil all of the criteria for authorship, every author of the manuscript must have made substantial contributions to ALL of the following aspects of the work:

- Conception and planning of the work that led to the manuscript or acquisition, analysis and interpretation of the data, or both; $\boldsymbol{A N D}$

- Drafting and/or critical revision of the manuscript for important intellectual content; $\boldsymbol{A N D}$

- Approval of the final submitted version of the manuscript.

$\triangle I$ certify that I fulfill ALL of the above criteria for authorship (PLEASE CHECK THE BOX).

\section{AUTHORSHIP CONTRIBUTION}

I certify that I have participated sufficiently in the work to take public responsibility for (PLEASE CHECK 1 OF THE 2 BOXES BELOW):

$\square$ Part of the content of the manuscript; $O R$

$\triangle$ The entire content of the manuscript.

\section{FUNDING DISCLOSURES}

\section{PLEASE CHECK 1 OF THE 2 BOXES BELOW:}

$\bigotimes$ I certify that no funding has been received for the conduct of this study and/or preparation of this manuscript; OR

I certify that all financial and material support for the conduct of this study and/or preparation of this manuscript is clearly described in the Compliance with Ethical Standards section of the manuscript.

Some funding organizations require that authors of manuscripts reporting research deposit those manuscripts with an approved public repository.

$\square$ Please check here if you have received such funding.

\section{E. CONTRIBUTOR DISCLOSURES}

All persons who have made substantial contributions to the work reported in the manuscript (e.g. data collection, data analysis, or writing or editing assistance) but who do not fulfill the authorship criteria MUST be named with their specific contributions in the Acknowledgments section of the manuscript. Groups of persons who have contributed may be listed under a heading such as 'Clinical investigators' and their function described. Because readers may infer their endorsement of the manuscript, all persons named in the Acknowledgments section MUST give the authors their written permission to be named in the manuscript.

I certify that all persons who have made substantial contributions to this manuscript but who do not fulfill the authorship criteria are listed with their specific contributions in the Acknowledgments section in the manuscript, and that all persons named in the Acknowledgments section have given me written permission to be named in the manuscript. 


\section{F. CONFLICT OF INTEREST DISCLOSURES}

A conflict of interest exists when professional judgment concerning a primary interest (such as patients' welfare or the validity of research) may be influenced by a secondary interest (such as financial gain or personal rivalry). A conflict of interest may arise for authors when they have a financial interest that may influence - probably without their knowing their interpretation of their results or those of others. We believe that to make the best decision on how to deal with a manuscript we should know about any such conflict of interest that the authors may have. We are not aiming to eradicate conflicts of interests - they are almost inevitable. We will not reject manuscripts simply because the authors have a conflict of interest, but we will publish a declaration in the manuscript as to whether or not the authors have conflicts of interests.

All authors MUST complete the following checklist:

\begin{tabular}{|c|c|c|c|}
\hline $\begin{array}{l}\text { Category } \\
\text { of potential } \\
\text { conflict of } \\
\text { interest }\end{array}$ & $\begin{array}{l}\text { If you h } \\
\text { subject } \\
\text { provide } \\
\text { When c } \\
\text { foresee }\end{array}$ & $\begin{array}{l}\text { e had an } \\
\text { atter disc } \\
\text { tails. If y } \\
\text { ppleting } t \\
\text { le future. }\end{array}$ & $\begin{array}{l}\text { entity that has a financial interest in the } \\
\text { leck the appropriate "Yes" box below and } \\
\text {, please check the appropriate "No" box. } \\
\text { th the last } 36 \text { months through to the }\end{array}$ \\
\hline & No $(\sqrt{ })$ & Yes $(\sqrt{ })$ & Details \\
\hline Employment & $\sqrt{ }$ & & \\
\hline $\begin{array}{l}\text { Grant received/grants } \\
\text { pending }\end{array}$ & $\sqrt{ }$ & & \\
\hline $\begin{array}{l}\text { Consulting fees or } \\
\text { honorarium }\end{array}$ & $\sqrt{ }$ & & \\
\hline $\begin{array}{l}\text { Support for travel to } \\
\text { meetings for the study, } \\
\text { manuscript preparation } \\
\text { or other purposes }\end{array}$ & $\sqrt{ }$ & & \\
\hline $\begin{array}{l}\text { Fees for participation in } \\
\text { review activities such } \\
\text { as data monitoring } \\
\text { boards, etc }\end{array}$ & $\sqrt{ }$ & & \\
\hline $\begin{array}{l}\text { Payment for writing or } \\
\text { reviewing the } \\
\text { manuscript }\end{array}$ & $\sqrt{ }$ & & \\
\hline $\begin{array}{l}\text { Provision of writing } \\
\text { assistance, medicines, } \\
\text { equipment or } \\
\text { administrative support }\end{array}$ & $\sqrt{ }$ & & \\
\hline $\begin{array}{l}\text { Payment for lectures } \\
\text { including service on } \\
\text { speakers bureaus }\end{array}$ & $\sqrt{ }$ & & \\
\hline Stock/stock options & $\sqrt{ }$ & & \\
\hline Expert testimony & $\sqrt{ }$ & & \\
\hline $\begin{array}{l}\text { Patents (planned, } \\
\text { pending or issued) }\end{array}$ & $\sqrt{ }$ & & \\
\hline Royalties & $\sqrt{ }$ & & \\
\hline $\begin{array}{l}\text { Other (err on the side } \\
\text { of full disclosure) }\end{array}$ & $\sqrt{ }$ & & \\
\hline
\end{tabular}


Every author MUST complete option 1 or option 2 as appropriate below. If you answered "Yes" to any of the questions relating to financial conflicts of interests in the table above (or if you wish to disclose a non-financial conflict of interest), you MUST write a suitable statement in the box below and include this statement in the Compliance with Ethical Standards section of the manuscript.

$\bigotimes$ I have no conflicts of interest to declare; OR

$\square$ The following statement regarding conflicts of interest and financial support for conduct of this study and/or preparation of this manuscript is to be published in the Compliance with Ethical Standards section of the manuscript:

Declaration: I certify that I have fully read and fully understood this form, and that the information that I have presented here is accurate and complete to the best of my knowledge.

Your name (please print): Lorenzo Lolli

Signature (please HAND-WRITE)

Date: $06 / 07 / 2020$ 